\title{
Comparative study of ruminal disorders with pathophysiology of ruminal fluid and hematological changes in sheep, Northwest Ethiopia
}

Shewatatek Melaku Asefa ( $\sim$ shewavet@gmail.com )

Department of Veterinary Science, College of Agriculture and Environmental Science, Bahir Dar University, Bahir Dar, Ethiopia;

\section{Abid Ali}

Department of Clinical Veterinary Medicine, College of Veterinary Medicine and Animal Sciences, University of Gondar, Ethiopia

\section{Birhanu Ayele}

Department of Clinical Veterinary Medicine, College of Veterinary Medicine and Animal Sciences, University of Gondar, Ethiopia

\section{Samuel Derso \\ Ashenafi Asefa \\ Birhan Agumas \\ Takele Adugna}

\section{Research article}

Keywords: Ruminal Dysfunction, Rumen fluid, Sheep

Posted Date: April 8th, 2020

DOI: https://doi.org/10.21203/rs.3.rs-20866/v1

License: (c) (i) This work is licensed under a Creative Commons Attribution 4.0 International License. Read Full License 


\title{
Comparative study of ruminal disorders with pathophysiology of ruminal fluid and hematological changes in sheep, Northwest Ethiopia

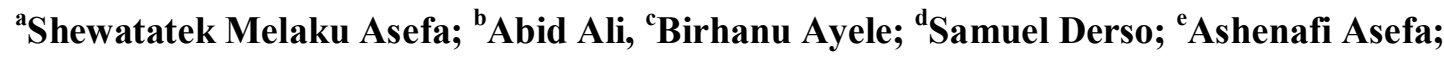 ${ }^{\mathrm{d}}$ Birhan Agumas; ${ }^{\mathrm{g}}$ Takele Adugna
}

${ }^{a}$ Department of Veterinary Science, College of Agriculture and Environmental Science, Bahir

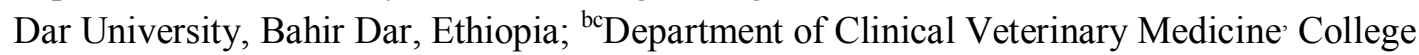
of Veterinary Medicine and Animal Sciences, University of Gondar, Ethiopia

\begin{abstract}
A cross-sectional study was conducted to determine prevalence and risk factors of ruminal disorders with identification of pathophysiological changes of rumen fluid and blood in sheep from January to June, 2019 in and around Gondar town, Northwest Ethiopia. One hundred seventy two sheep were selected by systematic random sampling technique and 21 apparently healthy sheep were selected by purposive sampling technique. Complete case history and clinical signs were recorded. Samples (rumen fluid and blood) were collected and analysed in the laboratory. The data was analysed using SPSS version 20. The prevalence of ruminal disorders in sheep was $55.2 \%$ and identified major types of ruminal disorders were simple indigestion (25.6\%), ruminal acidosis (20.35\%), ruminal tympany (5\%) and ruminal alkalosis (4.1\%). The most prominent clinical signs recorded in sheep with ruminal disorders were anorexia and inappetence followed by diarrhoea, dullness, dehydration, bloat and abdominal pain. Ruminal motility and protozoal motility were significantly $(p<0.05)$ reduced where as percentage of PCV was significantly increased $(p<0.05)$ in sheep's with ruminal disorders. Sedimentation activity time was significantly reduced in sheep with ruminal acidosis however, it was significantly $(p<0.05)$ increased in ruminal alkalosis $(p<0.05)$. Color, consistency and odour were affected during ruminal disorders. In multivariable logistic regression analysis showed that Male sex; (Adjusted Odds Ratio [AOR] = 6.044; 95\% CI: 1.894-19.281), extensive farming system $(A O R=6.358 ; 95 \% C I: 1.335-30.285)$, Crop residue and concentrate feed ( $A O R=23.01 ; 95 \%$ CI: 8.364-08.201), sudden change of feed ( $A O R=32.911$, 95\% CI: 7.959-136.092) and moldy feed (AOR=20.807, 95\%CI: 6.245-69.325) were significantly $(p<0.05)$ associated with occurrence of ruminal disorders in sheep.
\end{abstract}

\section{Keywords: Ruminal Dysfunction, Rumen fluid, Sheep}




\section{INTRODUCTION}

The ruminant stomach consists of a complex ecosystem where nutrients consumed by ruminants digested via fermentation process, which executed with diverse microorganisms such as bacteria, protozoa, and fungi. These diverse microorganisms affected by different gastrointestinal problems including ruminal disorders such as simple indigestion, ruminal acidosis, alkalosis, tympany and results in changes in rumen environment accompanied by clinical signs such as anorexia, diarrhoea, depression, dehydration, weakness and apathy (Agarwal et al., 2015).

Simple indigestion is characterized by inappetence to anorexia, atony of forestomch, lack of rumination, full stomach and diarrhoea (Tyagi et al., 2018). It is mainly caused by the dietary abnormalities of minor degree including indigestible ingestion of poor digestible roughage, particularly when the protein intake is low, ingestion of moldy feed, ingestion of damaged (cold or heat) feed, abrupt feed changes, and moderate excesses of grain and concentrate intake. Indigestible roughage may include straw, bedding or scrub fed during drought periods. Moreover, prolonged or heavy oral dosing with antimicrobials may cause indigestion due to inhibition of the normal ruminal flora [Asrat and Melkamu, 2015].

Ruminal acidosis is the condition in which the $\mathrm{pH}$ of ruminal fluid is generally less than 5.5. It develops from sudden ingestion of large quantity of carbohydrate rich diet, such as grain, causing proliferation of lactic acid producing bacteria in the rumen particularly Streptococcus bovis. The type of diet affects the number and species of bacteria and protozoa in the rumen and a change is required for microbial adaptation. Therefore, in the absence of this adaptation period, major decrease in ruminal $\mathrm{pH}$ leads to translocation of ruminal microflora causing ruminal atony with heavy mortality (Kothari et al.,2018).

Rumen alkalosis can occur with the generation of excessive ammonia in the rumen. Ammonia concentrations rise when high-protein diets are fermented. More dramatic, elevations in ammonia concentration with rumen fluid $\mathrm{pH}$ above 7.3 followed the overfeeding of non-protein nitrogen sources such as urea, biuret and ammonium phosphate (Kothari et al.,2018).

Ruminal tympany is abnormal distension of the rumen and reticulum caused by excessive retention of the gases of fermentation; either in the form of persistent foam mixed with the rumen contents (frothy bloat) or as free gas separated from the ingesta. According to the aetiology, we can define two different form of ruminal tympany; primary ruminal tympany or secondary ruminal tympany (Abdisa, 2018).

Ruminal disorders in sheep cause significant economic loss to the producers. In north western Ethiopia, due to the lack of intensive works on ruminal disorders, clinical characterizations as well as its associated 
factors are not well identified. Moreover, as per the case inflow of small ruminants of veterinary Clinics of north western Ethiopia reported large number of ruminal disorders (Amhara agricultural and livestock development Beraue, 2018). So, to effectively manage and control the problem, the types of ruminal disorders and its associated factors should be identified. Therefore, this study was to estimate the prevalence of ruminal disorders, assess its associated risk factors, evaluate pathophysiological changes in rumen liquor and also to evaluate hematological parameter in relation to ruminal disorders in sheep of the study area.

\section{MATERIALS AND METHODS}

\subsection{Study Area}

The study was conducted in and around Gondar, capital of Central Gondar zone in Amhara regional state, Northwest Ethiopia. It is located $750 \mathrm{~km}$ Northwest of the capital city, Addis Ababa and situated between $12^{\circ} 36^{\prime} \mathrm{N}$ and $33^{\circ} 28^{\prime} \mathrm{E}$ at an altitude of about $2300 \mathrm{~m}$ above sea level with an average temperature of $20^{\circ} \mathrm{C}$ and an average annual rainfall of $1800 \mathrm{~mm}$ (Metrology Agency, 2013).

\subsection{Study Design and Sampling Technique}

A cross-sectional study design was conducted from January 2018 to June, 2019 to determine the prevalence of rumenal disorders and its associated factors with identification of rumen fluid and blood pathophysiological changes in sheep of Northwest Ethiopia. One hundred seventy two sheep were selected by systematic randomly sampling technique from sheep that came to public veterinary clinics of the study area. Twenty one apparently healthy sheep were selected by purposive sampling technique from small holder farms.

\subsection{Sample Size Determination}

The sample size was determined according to (Thrusfield, 2005). Previous study conducted by Shah et al. (2013) on the prevalence of ruminal disorders in sheep showed $12.4 \%$. Therefore, using $12.4 \%$ as expected prevalence and 5\% absolute precision at 95\% confidence level.

$$
N=\frac{(1.96)^{2} \times P_{e p}\left(1-P_{e p p}\right)}{D^{2}}
$$

Where, $\mathrm{N}=$ Sample size; $\mathrm{P}_{\exp }=$ Expected prevalence; $\mathrm{D}^{2}=$ Absolute precision;

$$
\mathrm{N}=\frac{(1.96)^{2} \times 0.124(1-0.124)}{(0.05)^{2}}
$$


Accordingly, the estimated sample sizes were 167 sheep. Adding of 21 for sampling errors thus over all of 188. Out of which 21 apparently healthy local breed sheep were treated as control to compare the parameters with sheep having ruminal disorders.

\subsection{Data Collection Techniques}

\subsubsection{Anamnesis}

Complete history was recorded to build up a reasonable list for differential diagnosis. Detailed information regarding the type of diet, recent or historical changes in components and exposure to mouldy feed were recorded. The sheep's were examined and evaluated for vital signs such as temperature, heart rate, respiration and ruminal motility.

\section{Ruminal liquor}

Fifteen up to twenty milliliter of ruminal fluid was collected as per (Bassert, 2010).

\section{Ororuminal collection}

Ororuminal collection was accomplished with appropriate manual handling and restraining of the sheep. It was done by standing close to sheep, wrap arm around top of sheep's neck using hand to open mouth, and then the orogastric tube was passed through the mouth, down the throat and into the rumen. The tube was confirmed as being in the rumen by gurgling sounds heard as well as the scent of fermented rumen fluid (sour-sweetish) detected. Once the tube was confirmed to be in place, either of the two methods was used for collecting the fluids as denoted below:

First method the collection was begun by kinking the tube, which traps fluid in the end of the tube by negative pressure. The tube was swiftly and gently withdrawn and empties the fluids into the waiting vessel. Second method after confirming the placement of the tube in the rumen, the dosing syringe was attached to the tube and aspirate to maximum ability, then tube was kink and withdraw slowly and steadily; empty fluid immediately into collection vessel.

\section{Ruminocentesis}

Ruminocentesis was done to collect rumen liquor particularly from those severely ill sheep and which was unable to take by orogastric tube. A percutaneous aspiration technique was employed in which a 16gauge needle fitted to a $20 \mathrm{~mL}$ disposable syringe introduced in a vertical direction in the left lower flank of the sheep and fluid was aspirated. Blood was collected from jugular vein of sheep. Landmarks for puncture site was the left side, on a horizontal line level with the top of the patella about 15 to $20 \mathrm{~cm}$ 
posterior to the last rib. The ruminal fluid was analysed immediately for $\mathrm{pH}$, methylene blue reduction test and protozoal motility. The physical characteristics (colour, odour, consistency and sedimentation activity test) of ruminal fluid were done as per Mohamed (2014) method.

\subsubsection{Examination of Rumen Liquor}

\section{Physical rumen liquor examination}

Physical examination of rumen liquor was performed for its colour, smell, consistency and appearance.

\section{Sedimentation activity test and pH of ruminal fluid}

Fresh rumen fluid was added in to a test tube and kept for 4-8 minutes. The sedimentation or floatation activity was evaluated according the time taken by the feed particles to sediment or float, which was used to evaluate the microbial activity (Mohamed, 2014). PH of ruminal fluid was measured immediately after collection of ruminal liquor by ruminocentesis from ruminal disorder suspected sheep using AD $111 \mathrm{PH}$ meter.

\section{Methylene blue reduction test}

Methylene blue reduction test (MBRT) was done to assess the number of functional anaerobic bacteria available within the rumen. A test tube was filled up with $10 \mathrm{~mL}$ of fresh rumen liquor. To this $0.5 \mathrm{~mL}$ of a $0.03 \%$ solution of Methylene Blue stain was added and a timer was set. Length of time takes for the rumen solution to clear of colour methylene blue was recorded. The solution which cleared within 2-6 minutes was indicative of adequate bacterial activity; greater than 6 up to $<10$ minutes was considered as medium bacterial activity and if $>10$ minutes was considered as having inadequate number of bacterial activity according to (Bassert, 2010).

\section{Ruminal protozoal motility}

Ruminal protozoal motility was recorded after collection of fresh rumen liquor.

\section{Blood collection and hematological analysis}

Owing to the resentment encountered by various owners, blood samples were collected the sheep. From each animal, about $5 \mathrm{~mL}$ whole blood was collected aseptically with the help of a disposable syringe from the jugular vein and transferred into the screw capped tubes containing $0.5 \mathrm{ml}$ of $1 \%$ ethylene diamine tetra acetate (EDTA) solution as an anticoagulant. The $\mathrm{pH}$ of blood, red blood cell (RBC), PCV and $\mathrm{Hb}$ were determined as described by Zein-Eldin et al., (2014). 


\subsection{Data Management and Analysis}

The collected data was entered and thoroughly screened for errors, and then analysis using SPSS version 20. Univariate and multivariate logistic regression analysis were conducted to assess the association between dependent and independent variable. Independent t-test was used to compare ruminal fluid and haematological values between healthy control and sheep with ruminal disorders. P-value $<0.05$ was considered as statistically significant with $95 \%$ confidence level (CI).

\subsection{Ethical considerations}

The study protocol was reviewed and approved by the Institution Review Board of College of Veterinary Medicine and Animal Sciences, University of Gondar (Ref.No. VCM 0241/2017). Official permission was also obtained from the respective bodies at Amhara Regional livestock development agency. Verbal informed consent was obtained from each study unit owners after being informed about the study.

\section{RESULTS AND DISCUSSIONS}

\subsection{Prevalence of Ruminal Disorders in Sheep}

Out of 172 sheep 95 (55.2\%) were with ruminal disorders. The highest prevalence of ruminal disorder among sheep came to veterinary clinics recorded was simple indigestion, $25.6 \%$, followed by ruminal acidosis, ruminal tympany and ruminal alkalosis with the prevalence of $20.35 \%, 5 \%$ and $4.1 \%$, respectively.

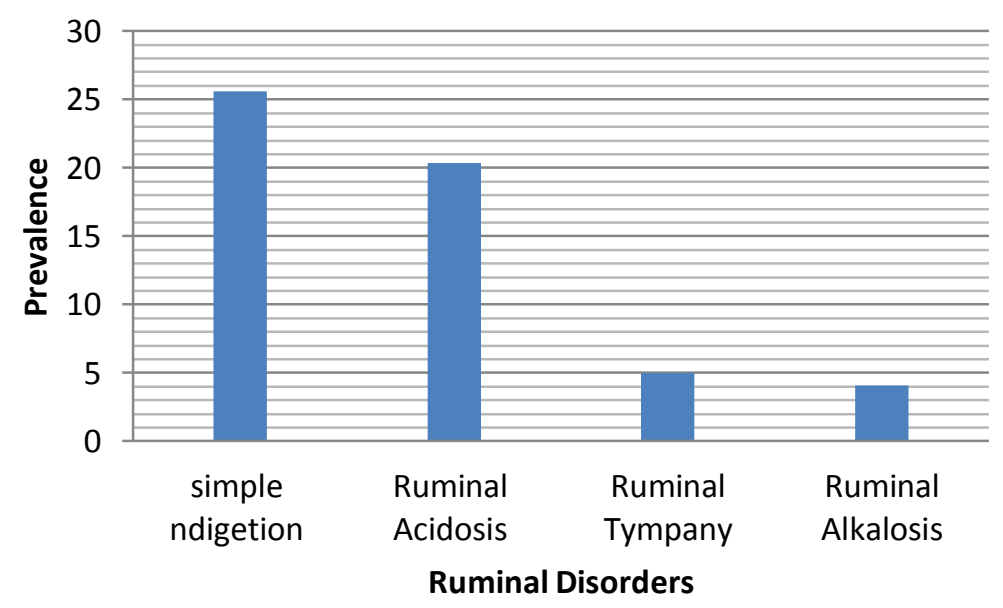

Figure 1: Prevalence of major ruminal disorders in sheep 
In the current study, the prevalence of ruminal disorder (55.2\%)) was higher than the findings of Shah et al. (2013) who stated that the prevalence of ruminal disorder in sheep was $12.4 \%$. The prevalence of simple indigestion noted in this study was $(25.6 \%$,). This finding is higher than the study finding of Shah et al. (2013) who stated that the prevalence of simple indigestion in sheep was $18.04 \%$. This might be due to improper feeding management such as feeding excessive amounts of non-structural carbohydrates and highly fermentable forages and insufficient dietary coarse fibre (Plaizie et al., 2008). In the present study, the prevalence of ruminal acidosis in sheep was (20.35\%). This prevalence was lower than the findings of $32.13 \%$ by Suresh et al. (2006), $42.1 \%$ by Henning et al. (2010) and $9.02 \%$ by Shah et al. (2013). These variations might be as a result of different management practices. In this study, sheep rearing in semi intensive farming system was significantly associated with bloat in sheep which is in agreement with Lessire and Knapp (2017) and Bailey (2014). This might be due to the fact that sheep rearing in semi intensive farming system were exposed to roughage and concentrate feed without any regularity in the study area. Feeding mouldy feed was also significantly associated with the occurrence of ruminal tympany (bloat).

\subsection{Clinical Findings Recorded in Sheep with Ruminal Disorders}

In the present study, the most prominent clinical sign recorded in sheep with simple indigestion was diarrhoea $(81 \%)$. Respiratory rate of sheep suffering from simple indigestion was significantly $(\mathrm{p}<0.01)$ increased as compared to healthy sheep's. However, ruminal motility of sheep's suffering from simple indigestion was significantly $(\mathrm{P}<0.05)$ decreased as compared to healthy sheep. Among the sheep's suffering from ruminal acidosis, major clinical sign recorded was anorexia (97\%) whereas in ruminal alkalosis was (86\%) (Table-1).

Table 1: Clinical findings of ruminal disorders in sheep

\begin{tabular}{lllll}
\hline \multicolumn{4}{c}{ Types of ruminal Disorders } \\
\hline Clinical sign & Simple & Ruminal & Ruminal & Ruminal \\
indigestion & acidosis & Tympany & alkalosis \\
\hline Anorexia and In appetence & $74 \%(33)$ & $97 \%(33)$ & $98 \%(8)$ & $86 \%(6)$ \\
Dullness & $79 \%(35)$ & $91 \%(31)$ & $73 \%(6)$ & $79 \%(5)$ \\
Diarrhoea & $81 \%(36)$ & $84 \%(29)$ & $12 \%(1)$ & $35 \%(2)$ \\
Bloat & $23 \%(10)$ & $53 \%(18)$ & $100 \%(9)$ & $15 \%(1)$ \\
Abdominal Pain & $12 \%(5)$ & $71 \%(24)$ & $24 \%(2)$ & $51 \%(4)$ \\
Dehydration & $8 \%(4)$ & $76 \%(26)$ & $64 \%(6)$ & $48 \%(3)$ \\
\hline
\end{tabular}


In the present study, the heart and respiratory rate of sheep's suffering from ruminal acidosis were significantly $(\mathrm{p}<0.01)$ increased as compared to healthy control group. Moreover, rectal temperature as well as ruminal motility were significantly $(\mathrm{p}<0.01)$ decreased when compared to healthy control group. Respiratory rate was significantly $(\mathrm{p}<0.01)$ increased in sheep with ruminal alkalosis as compared to healthy group. In comparison to both acidotic sheep's and healthy group, the ruminal motility was significantly $(\mathrm{p}<0.01)$ reduced and graded as low motility $(71.4 \%)$ and completely absent motility $(28.6 \%)$ in sheep's suffering from alkalosis. Moreover, there was no significant difference in heart rate and rectal temperature of sheep's affected with ruminal acidosis when compared to healthy group. Heart and respiration rate were significantly $(\mathrm{p}<0.01)$ increased, whereas ruminal motility was significantly $(\mathrm{p}<0.01)$ decreased in sheep with tympany as compared to healthy one (Table-2).

Table 2: Mean values of vital signs of clinically healthy sheep and with ruminal disorders

Types of ruminal Disorders

\begin{tabular}{llllll}
\hline Parameter & $\begin{array}{l}\text { Healthy } \\
\text { control }\end{array}$ & $\begin{array}{l}\text { Simple } \\
\text { Indigestion }\end{array}$ & $\begin{array}{l}\text { Ruminal } \\
\text { Acidosis }\end{array}$ & $\begin{array}{l}\text { Ruminal } \\
\text { Tympany }\end{array}$ & $\begin{array}{l}\text { Ruminal } \\
\text { Alkalosis }\end{array}$ \\
\hline Temperature & $39.09 \pm 0.06$ & $39.17 \pm 0.051$ & $37.07 \pm 0.123^{* *}$ & $38.53 \pm 0.132$ & $39.76 \pm 0.163$ \\
$\begin{array}{l}\text { Heart Rate/m } \\
\text { Respiratory }\end{array}$ & $75.05 \pm 1.39$ & $86.73 \pm 0.761$ & $100.53 \pm 1.247^{* *}$ & $93.71 \pm 3.220^{* *}$ & $101.11 \pm 2.908$ \\
$\begin{array}{l}\text { rate /m } \\
\text { Ruminal }\end{array}$ & $23.43 \pm 2.29$ & $43.23 \pm 0.958^{*}$ & $47.44 \pm 1.129^{* *}$ & $55.43 \pm 5.268^{* *}$ & $56.44 \pm 2.534^{* *}$ \\
motility/5min & $6.21 \pm 0.43$ & $4.21 \pm 0.31^{*}$ & $2.03 \pm 0.51^{* *}$ & $1.89 \pm 0.51^{* *}$ & $2.47 \pm 0.61^{* *}$ \\
\hline
\end{tabular}

Min $=$ minute $\quad *=\mathrm{P}<0.05 * *=\mathrm{P}<0.01 * * *=\mathrm{P}<0.001$

With regard to clinical signs, the sheep's suffering from simple indigestion showed anorexia and in appetence, followed by dullness, diarrhoea, bloat, abdominal pain and dehydration. This result is in close agreement with the study finding of Lessire and Knapp (2017) who also reported similar findings. Regarding physical parameters, there was no significant difference in vital signs (body temperature, heart rate and respiratory rate) between sheep having simple indigestion and control group. This finding was in consistent with findings of Shah et al. (2017) who also reported similar findings. This might be due to the fact that simple indigestion is not usually a fatal disease. Moreover, in this condition, there is no systemic reaction therefore, pulse, temperature and respiration rates was not affected (Shah et al., 2017). Ruminal motility of sheep with simple indigestion was significantly $(\mathrm{p}<0.05)$ reduced as compared to control group. This finding was in agreement with the study conducted by Shah et al. (2017). 
In this study, the major clinical signs recorded during ruminal acidosis were anorexia, in appetence, dullness, diarrhoea, bloat, abdominal pain and dehydration. This result was coincided with Shah et al. (2013). These clinical signs observed might be due to the fact that acidosis leads to depression of all the centres in the central nervous system. Moreover, it may also be due to disintegration of gram negative bacteria (normal microflora) which releases endotoxin causing endotoxemia (Mohamed, 2014). Diarrhoea due to ruminal acidosis might be because of significant production of volatile fatty acids and lactic acid. This was as a result of the lactate-metabolizing protozoa are lost at a lower $\mathrm{pH}$, the lactate which is osmotically active remains in the small intestine and colon can contribute to an osmotic pull of water through the para-cellular spaces and into the intestinal lumen causing diarrhoea (Lessire and Knapp, 2017). Bloat during ruminal acidosis might be due to a sudden increase in fermented carbohydrates in the rumen leading to rapid microbial overgrowth and subsequent cell lysis. Extracellular bacterial mucopolysaccharides (slime) and stored carbohydrates released during microbial cell lysis increase the viscosity of ruminal fluid trapping gas and forming the stable foam that leads to bloat (McAllister et al., 2005).

The presence of abdominal pain during ruminal acidosis might be as a result of lactic acid, which can cause severe damage to the rumen wall enabling bacterial or fungal invasion of the body. The dehydration at the time of ruminal acidosis might be due to loss of water from the blood which results an increase blood osmolality and packed cell volume, leading to dehydration in the animal. Furthermore, rate of absorption of VFA from the rumen is enhanced at low $\mathrm{pH}$. When acid absorption exceeds metabolism, these compounds can accumulate in blood and increase blood osmolality further (Penner et al., 2007).

In the present study, temperature of acidotic sheep was significantly $(p<0.01)$ reduced as compared to control group. This finding is in agreement with the study findings of Shah et al. (2013). This might be due to the reduction in metabolism and hence, dehydration resulting from the loss of intravenous cellular fluid into the rumen and from osmotic diarrhoea. In this study, heart rate was significantly $(\mathrm{p}<0.01)$ increased as compared to the control group. Similar results were observed by Mousa et al. (2013). The increased heart rate might be due to accumulated lactic acid that after absorption caused severe acidosis, hemoconcentration, fall in plasma volume and circulatory failure (Shah et al., 2013). In the current study, the respiratory rate was also significantly $(\mathrm{p}<0.01)$ increased as compared to the healthy control. This finding is also reported by Mohamed (2014). The increased respiratory rate might be explained by stimulation of respiratory centres by lowed $\mathrm{pH}$ (Radostits et al., 2007). Regarding rumen motility, the present study revealed that there was significant $(p<0.01)$ reduction of rumen motility in acidotic sheep than control group. Similar results were also observed by Mousa et al. (2013). The reduction of rumen 
motility might be due to failure of muscular contractions of rumen/ reticulum because of accumulation of lactic acid leading to chemical ruminitis.

The reported clinical signs of animals suffering from ruminal alkalosis were in accordance with Radostits et al., (2007), Karapinar et al. (2008), Mohamed (2014) and Shah and Hussain (2017). Respiration rate were found to be significantly $(\mathrm{p}<0.001)$ increased whereas ruminal motility $(\mathrm{p}<0.001)$ decreased in animals with ruminal alkalosis. This result is similar as reported earlier by Shah and Hussain (2017). The increased heart rate might be due to fall in plasma volume and effects of ammonia on central nervous system. Moreover, the increase in respiration rate could be attributed to accelerated pulmonary ventilation to excrete excess amount of ammonia from blood through lungs or due to stimulation (Radostits et al., 2000). In the current study, the recorded clinical signs were anorexia, inappetence, dullness, diarrhoea, bloat, abdominal pain and dehydration. Similar observations were reported by other authors like: Leonardo et al. (2014), Zein-Eldin et al. (2014) and Lessire and Knapp (2017). All clinical signs observed during ruminal tympany (bloat) might be due to the facts that if the inner tube is the stomach and intestine and the outer tube represents the wall of the abdomen, any change in the volume and pressure of the inner tube would affect the outer tube, though this may be simplistic, only two sections of the outer tube, the front and side muscles of abdomen and the diaphragm (the muscle under the lungs that separates the chest and abdomen and facilitates breathing movements) actually have room to expand (Suarez \& Busetti, 2009)). In the current study, body temperature, heart rate and respiratory rate were significantly $(\mathrm{p}<0.01)$ increased. These findings are in agreement with the study conducted by Mohamed (2014). The increased respiratory and heart rate might be due to the fact that interference of enlarged stomach with the relaxation and contraction of diaphragm and shortage of oxygen to the body (Lessire and Knapp, 2017). In this study, ruminal motility was significantly $(\mathrm{P}<0.01)$ reduced. This result is in agreement with the study conducted by Lessire and Knapp (2017). The decreased ruminal motility during ruminal tympany is due to the fact that during bloat all cells of the wall of stomach will stretch and resulting pain which hinder the motility of rumen.

\subsection{Physical and Other Characteristics of Ruminal Fluid among Ruminal Disordered Sheep}

The colour of the rumen fluid from majority of sheep's suffering from simple indigestion, ruminal acidosis, ruminal alkalosis and in bloated sheep was as dipected in Table; (3). 
Table 3: Physical characteristics of ruminal liquor

\begin{tabular}{llllll}
\hline \multicolumn{5}{c}{ Ruminal Liquor } \\
\hline Parameter & $\begin{array}{l}\text { Healthy } \\
\text { control }\end{array}$ & $\begin{array}{l}\text { Simple } \\
\text { Indigestion }\end{array}$ & $\begin{array}{l}\text { Ruminal } \\
\text { acidosis }\end{array}$ & Bloat & $\begin{array}{l}\text { Ruminal } \\
\text { Alkalosis }\end{array}$ \\
\hline Colour & $\begin{array}{l}\text { Yellowish } \\
\text { brown }\end{array}$ & Brownish green & Milky grey & Light brown & Brownish green \\
Odour & Aromatic & Aromatic & Pungent sour & Putrid ammonia & Fermented \\
& Slightly & Lightly viscous & Slimy aqueous & Thin aqueous & Slimy viscous \\
Vonsistency & & & & \\
\hline
\end{tabular}

Regarding rumen fluid analysis, the colour of rumen fluid taken from a majority of sheep's affected with simple indigestion was brownish green and has a minor difference from control group. This result was in agreement with the study finding of Ding and $\mathrm{Xu}$ (2006). The minor difference in colour of rumen fluid could be due to the minor changes in the environment of rumen and reticulum (Radostits et al., 2007). In the present study, the consistency of rumen fluid taken from sheep's affected with simple indigestion was lightly viscous and there was no major difference when compared to the control group. The minor difference in the consistency of rumen fluid might be as a result of minor feed changes that usually affects the process of normal digestion (Leonardo et al., 2014). Concerning odour of rumen fluid, the majority of rumen fluid taken from sheep affected by simple indigestion was aromatic odour and there was no difference from the control group. In this finding, the colour of rumen fluid obtained from acidotic sheep was different from control one and the majority of these affected sheep's were having milky grey colour. This result is in agreement with the study findings of Randhawa et al. (1989) who also reported that in lactic acidosis of buffalo calves the colour of rumen liquor changed from brownish yellow to greyishyellow. The change of colour of rumen fluid from yellowish brown to milky grey might arise from excessive feeding on a concentrated diet such as Dashen brewery and other by-products.

In the present study, the smell of ruminal fluid obtained from acidotic sheep was different from the control group (aromatic odour) and the smell was pungent sour. Similar findings were observed by James (2011).

The protozoal motility during simple indigestion was graded as high motility $(27.3 \%)$ and moderate motility (72.7\%). The range of rumen liquor $\mathrm{pH}$ was found in both acidic and alkaline sides (5.6-6.5 in acidic side and 6.8-7.3 in alkaline side). From the study result shown at table 4, the protozoal motility was completely absent or reduced in acidotic sheep. It is important to reveal that rumen protozoal motility 
was graded as low motility (25.7\%) and completely absent motility $(74.3 \%)$ in acidotic sheep. In the present study, sedimentation activity time and $\mathrm{pH}$ of rumen fluid of sheep's affected with ruminal acidosis was significantly $(\mathrm{p}<0.01)$ reduced $(\mathrm{pH}=4.80-4.93)$ as compared to healthy sheep's. However, methylene blue reduction time was significantly $(\mathrm{p}<0.01)$ increased as compared to healthy control. The $\mathrm{pH}$ of rumen fluid was significantly $(\mathrm{p}<0.01)$ increased $(\mathrm{pH}=7.3-7.37)$ as compared to healthy group. Sedimentation activity test and methylene blue reduction test conducted on rumen fluid of alkalosis sheep's indicates that significantly increased $(\mathrm{p}<0.01)$ as compared with healthy control group. The protozoal motility was reduced and graded as low motility (77.8\%) and completely absent motility $(22.2 \%)$ in animals suffering from tympany. Moreover, SAT and MBRT were increased significantly $(\mathrm{p}<0.01)$ in sheep as compared to control group (Table-4).

Table 4: Mean values \pm S.E of SAT, $\mathrm{pH}$ and MBRT in ruminal fluids of clinically healthy sheep and those suffering from ruminal disorders

Types of ruminal Disorders

\begin{tabular}{|c|c|c|c|c|c|}
\hline Parameter & $\begin{array}{l}\text { Healthy } \\
\text { control }\end{array}$ & Simple Indigestion & $\begin{array}{l}\text { Ruminal } \\
\text { Acidosis }\end{array}$ & $\begin{array}{l}\text { Ruminal } \\
\text { Tympany }\end{array}$ & Ruminal Alkalosis \\
\hline $\begin{array}{l}\text { Protozoal } \\
\text { Activity }\end{array}$ & +++ & $\begin{array}{l}+++(27.3 \%),++ \\
(72.7 \%)\end{array}$ & $\begin{array}{l}\mathrm{O}(25.7 \%), \\
+(74.3 \%)\end{array}$ & $\begin{array}{l}\mathrm{O}(22.2 \%) \\
+(77.8 \%)\end{array}$ & $\begin{array}{l}\text { O }(28.6 \%), \\
+(71.4 \%)\end{array}$ \\
\hline SAT (min) & $4.5 \pm 0.32$ & $6.03 \pm 0.543$ & $2.24 \pm 0.161^{* *}$ & $18.29 \pm 1.769^{* * *}$ & $14.56 \pm 1.314^{* *}$ \\
\hline $\begin{array}{l}\text { pH of ruminal } \\
\text { fluid }\end{array}$ & $6.65 \pm 0.15$ & $\begin{array}{l}6.05 \pm 0.45 \text { in acidic } \\
\text { side, } 7.05 \pm 0.25 \text { in } \\
\text { alkaline side } \\
6.48 \pm .086\end{array}$ & $4.87 \pm 0.061^{* *}$ & $7.77 \pm 0.127$ & $7.33 \pm 0.044^{* *}$ \\
\hline MBRT (min) & $3.8 \pm 0.27$ & $4.24 \pm 0.275$ & $15.07 \pm 0.454^{* *}$ & $7.64 \pm 0.472^{*}$ & $13.82 \pm 0.891^{* *}$ \\
\hline
\end{tabular}

$*=\mathrm{P}<0.05 * *=\mathrm{P}<0.01 * * *=\mathrm{P}<0.001 ;+++=$ high motility, $++=$ moderate motility,$+=$ low motility $0=$ no motility

Regarding the sedimentation activity test (SAT), there was no significant difference in SAT of rumen fluid taken from sheep suffering from simple indigestion with the control group. However, there was slight increasing trend in time taken to sediment the rumen fluid from sheep with simple indigestion as 
compared control group. This result was in agreement with Radostits et al. 2007), which stated that the difference in time taken to sediment might be type of feed taken and time of feeding. Concerning the methylene blue reduction test (MBRT), there was no statistically significant difference in MBRT between sheep's suffering from simple indigestion and the control group. This result was in agreement with Leonardo et al. (2014). In the present study, the sedimentation activity test was significantly $(\mathrm{p}<0.01)$ reduced when compared to the control group. This result is in contradiction with the study findings of Randhawa et al. (1989), who reported a complete absence of SAT in acidosis which persisted throughout the period of observation. This variation might be due to the consumption of different types of feed that the affected sheep's might have taken (Radostits et al., 2007).

In the present study, $\mathrm{pH}$ of ruminal fluid was significantly $(\mathrm{p}<0.01)$ reduced when compared to the control group. This result is in agreement with other authors like: Gregory et al. (2010), Shah et al. (2013) and Leonardo et al. (2014). The reduction in $\mathrm{pH}$ in sheep's having ruminal acidosis is due to the fact that excessive production of short chain fatty acid (SCFA) and accumulation of acid results in the reduction of the ruminal $\mathrm{pH}$ leading to ruminal acidosis (grain overload). Regarding MBRT, there was significant $(p<0.01)$ increase in methylene blue reduction time in rumen fluid obtained from sheep having ruminal acidosis as compared the control group. This finding is in agreement with the study of Shah et al. (2013). The increased methylene blue reduction time in rumen fluid obtained from sheep affected with ruminal acidosis might be due to an increased gram-positive bacteria population, as they grow maximally at a low $\mathrm{pH}$ causing bacterial translocation; whereas the population of gram-negative bacteria is decreased or absent (Suarez \& Busetti, 2009).

Moreover, the lactate-producing bacteria, Streptococcus bovis increases, in acute ruminal acidosis, while lactate-utilizing species decrease. With a decrease in lactate-utilizing bacteria, lactate accumulates in the rumen during acute lactic acidosis. This will contribute further to a decreased or complete defaunation of ciliated protozoa in a low ruminal $\mathrm{pH}$ environment; and as a result the methylene blue reduction test (also called methylene blue decolourisation test), a decrease in the time necessary to convert the blue colour to white colour, as an index of redox potential (Shah et al., 2013).

Ruminal pH, SAT and MBRT of sheep's suffering from alkaline indigestion were found to be significantly $(\mathrm{p}<0.001)$ increased which also in agreement with the findings of Shah and Hussain (2017). The increase in ruminal $\mathrm{pH}$ might be due to poor buffering capacity of ruminal fluid against production of large quantity of ammonia (Leonardo et al., 2014). The significant increase in SAT and MBRT could be ascribed to the destruction of normal rumen micro flora due to disturbed $\mathrm{pH}$ and accumulation of toxic levels of ammonia and other amines (Bailey, 2014). In the present study, the protozoal motility of animals 
suffering from alkaline indigestion was analyzed and graded. Karapinar et al. (2008) recorded similar findings in sheep with alkalosis. The reason for the development altered protozoal motility might be due to improper utilization and storage of glycogen by rumen protozoa affected by toxic levels of ammonia.

\subsection{Hematological Changes among Ruminal Disordered Sheep}

The blood $\mathrm{pH}$ was significantly $(\mathrm{p}<0.01)$ reduced as compared to healthy animals. Haematological analysis of sheep's suffering from acidosis was performed as per established methods. Haemoglobin $(\mathrm{Hb})$ estimation recorded showed a significant $(\mathrm{p}<0.05)$ increase as compared to healthy group. Parameters such as packed cell volume (PCV) and total erythrocyte were significantly $(p<0.01)$ increased when compared with healthy group. Haematological analysis revealed significant $(\mathrm{p}<0.01)$ increase in packed cell volume as compared to healthy group. Similar trend was observed with hemoglobin which was significantly $(\mathrm{p}<0.05)$ increased as compared to healthy group. Significant $(\mathrm{p}<0.05)$ increase in PCV was recorded in sheep affected with ruminal tympany as compared to control group. However, there was nonsignificant difference in blood $\mathrm{pH}, \mathrm{Hb}$ and total erythrocyte count when compared to healthy control group (Table-5).

Table 5: Mean values \pm S.E hematological parameters of clinically healthy sheep and those suffering from ruminal disorders

\section{Types of ruminal Disorders}

\begin{tabular}{lccccc}
\hline Parameter & $\begin{array}{c}\text { Healthy } \\
\text { control }\end{array}$ & $\begin{array}{c}\text { Simple } \\
\text { Indigestion }\end{array}$ & $\begin{array}{c}\text { Ruminal } \\
\text { Acidosis }\end{array}$ & $\begin{array}{c}\text { Ruminal } \\
\text { Tympany }\end{array}$ & $\begin{array}{c}\text { Ruminal } \\
\text { Alkalosis }\end{array}$ \\
\hline Blood pH & $7.41 \pm 0.004$ & $7.35 \pm 0.014$ & $7.16 \pm 0.015^{* *}$ & $7.35 \pm 0.025$ & $7.27 \pm 0.020$ \\
PCV (\%) & $37.35 \pm 0.39$ & $36.95 \pm 0.243$ & $46.09 \pm 0.339^{* *}$ & $38.98 \pm 0.121^{*}$ & $42.78 \pm 1.020^{* *}$ \\
Hb $(\mathbf{g} / \mathbf{1 0 0} \mathbf{m l})$ & $12.74 \pm 0.15$ & $12.49 \pm 0.091$ & $14.62 \pm 0.129^{*}$ & $12.42 \pm 0.211$ & $13.69 \pm 0.282^{*}$ \\
TEC $\left(\mathbf{1 0 0}^{\mathbf{6}} \mathbf{~ m m}^{\mathbf{3}}\right)$ & $12.92 \pm 0.14$ & $12.52 \pm 0.079$ & $14.67 \pm 0.088^{* *}$ & $12.24 \pm 0.122$ & $13.22 \pm 0.300$ \\
\hline$*=\mathrm{P}<0.05^{* *}=\mathrm{P}<0.01 * * *$ \\
\hline
\end{tabular}

$*=\mathrm{P}<0.05 * *=\mathrm{P}<0.01 * * *=\mathrm{P}<0.001$

In the present study, there were no statistically significant difference in hematological parameters ( $\mathrm{pH}$ of blood, Red blood cell (RBC), PCV and $\mathrm{Hb}$ ) between sheep's affected with simple indigestion and the control group. Blood pH did not differ significantly between sheep's with alkalosis and control. Stabilization in the blood $\mathrm{pH}$ despite ruminal alkalosis could be attributed to buffering action of blood and different compensatory mechanisms such as pulmonary hyperventilation. 


\subsection{Rumenal Disorders Associated with Risk Factors}

In the bivariate analysis and Multivariable logistic regression analysis showed that sex, farming system, type of feed, sudden change of feed and ingestion of mouldy feed were significantly associated risk factors with occurrence of ruminal disorders of sheep. In multivariable logistic regression analysis showed statically value of; Male sex; (Adjusted Odds Ratio [AOR] $=6.044 ; 95 \%$ CI: 1.894-19.281), extensive farming system $(\mathrm{AOR}=6.358 ; 95 \% \mathrm{CI}: 1.335-30.285)$, Crop residue and concentrate feed (AOR=23.01; 95\% CI: 8.364-08.201), sudden change of feed (AOR=32.911, 95\% CI: 7.959-136.092) and moldy feed (AOR=20.807, 95\%CI: 6.245-69.325) (Table 6). 
Table 6: Association between occurrences of ruminal disorders with different risk factors

\begin{tabular}{|c|c|c|c|c|c|c|}
\hline \multicolumn{7}{|c|}{ Types of ruminal Disorders } \\
\hline Variables & Category & $\begin{array}{c}\text { Number } \\
\text { Examined }\end{array}$ & $\begin{array}{c}\text { Number } \\
\text { Positive (\%) }\end{array}$ & COR (CI: 95\%) & AOR (CI: 95\%) & P-value \\
\hline & Male & 118 & $69(58.47)$ & $2.62(1.29,5.57)$ & $6.04(1.84,19.28)$ & 0.002 \\
\hline Farming system & Extensive & 101 & $45(44.55)$ & 1 & 1 & \\
\hline \multirow{4}{*}{ Body condition } & Normal & 94 & $51(54.25)$ & 1 & 1 & \\
\hline & Very Fat & 11 & $7(63.63)$ & $0.29(0.04,1.769)$ & $0.099(0.005,1.972)$ & 0.130 \\
\hline & Fat & 26 & $15(57.7)$ & $0.22(0.43,1.143)$ & $0.064(0.004,1.007)$ & 0.051 \\
\hline & Thin & 32 & $15(46.87)$ & $0.24(0.05,1.223)$ & $0.217(0.016,2.895)$ & 0.248 \\
\hline Types of feed & $\begin{array}{l}\text { Crop residue \& } \\
\text { concentrate }\end{array}$ & 63 & $37(58.73)$ & $31.401(10.082,64.902)$ & $23.01(8.364,108.201)$ & 0.020 \\
\hline \multirow{2}{*}{ Sudden change of feed } & No & 98 & $31(27.68)$ & 1 & 1 & \\
\hline & Yes & 74 & $64(86.48)$ & $28.350(10.415,77.166)$ & $32.911(7.959,136.092)$ & 0.000 \\
\hline \multirow{2}{*}{ Ingestion of mouldy feed } & No & 104 & $41(39.42)$ & 1 & 1 & \\
\hline & Yes & 68 & $54(79.41)$ & $20.974(9.297,47.315)$ & $20.807(6.245,69.325)$ & 0.001 \\
\hline
\end{tabular}

${ }^{*} \mathrm{COR}=$ Crude odds ratio, $\mathrm{AOR}=$ Adjusted odds ratio, $\mathrm{P}<0.05=$ statistically significant 
The odd of having ruminal disorder was 6 times more likely to occur in male sheep than female (Adjusted Odds Ratio $[\mathrm{AOR}]=6.044 ; 95 \%$ CI: 1.894-19.281). This finding is in agreement with Suarez \& Busetti (2009). The difference in sex might be due to feeding of highly digestible carbohydrate rich feed for male sheep because they were preferable for fattening in the study area. Concerning farming system, sheep in extensive, semi-intensive and intensive farming system had ruminal disorders of $44.55 \%, 64 \%$ and $85.7 \%$ respectively. The risk of acquiring ruminal disorder in intensive farming system was almost 6 times more likely than sheep in the extensive farming system ( $\mathrm{AOR}=6.358 ; 95 \% \mathrm{CI}: 1.335-30.285)$. In this study, the prevalence of ruminal disorder was significantly associated with farming system, which is in consistent with the report of Mohamed (2014). Taking in to consideration the types of feed provided to the sheep in the study area were grazing \& crop residue (46.8\%); crop residue and hay (59\%); crop residue and concentrate $(58.73 \%)$. The odd of having ruminal disorder was 23 times more likely to occur in sheep fed crop residue and concentrate than sheep in freely grazing and feeding crop residue ( $\mathrm{AOR}=23.01 ; 95 \% \mathrm{CI}$ : 8.364-08.201). This might be mainly due to availability of hotel wastes like boiled rice, baker's waste, rotten potatoes and an increase in ration grain that overwhelms buffering ability of rumen bacteria leading to reduced performance and sometimes death (Lessire and Knapp, 2017).

In the present study, $86.48 \%$ of the study sheep were exposed to sudden change of feed and $79.41 \%$ sheep were taken mouldy feed. The risk of having ruminal disorder in sheep exposed to sudden change of feed was almost 33 times than in sheep without sudden change (constant amount and time) of feed (AOR=32.911, 95\% CI: 7.959-136.092). This finding is in agreement with the finding of Suarez \& Busetti (2009). Increased prevalence of rumenal disorder as a result of sudden change of feed might be due to the due to the fact that microorganism need time for adaptation of different types of feed as a result simple indigestion (Radostits, et al., 2007). The risk of acquiring ruminal disorder in sheep feeding moldy feed was nearly 20 times more likely than sheep didn't feed moldy feed (AOR=20.807, 95\%CI: 6.24569.325). This finding was also in line with the findings of Leonardo et al. (2014). High prevalence of rumenal disorder in sheep feeding mouldy feed might be due to consumption of mould-contaminated feed, and also, the levels of pancreatic lipase, amylase, trypsin, and chymotrypsin may be significantly reduced. This reduction in pancreatic enzyme levels results in insufficient digestion and absorption of protein, fat and carbohydrates (Shah and Hussain, 2017). 


\section{CONCLUSION AND RECOMMENDATIONS}

During this study, overall prevalence of ruminal disorder was half of the sheep cases attended in veterinary clinic. Out of this, the highest prevalence recorded was simple indigestion which was quarter of the cases, followed by ruminal acidosis, which was one fifth of the over all the cases attended in clinic. Unlimited numbers of cases of ruminal tympany and ruminal alkalosis were also recorded. The prevalence of ruminal disorders were significantly associated with abrupt change of feed, feeding of excess carbohydrate diet, feeding of mouldy feed and feeding on decayed or putrefied materials as garbage. Therefore proper feeding practice with constant feeding patter in amount and time should be followed. Roughage and concentrate feed should be balanced and avoid decayed and mouldy feed during ration formulation. There was significantly variation in colour, consistency and odour of rumen fluid between control group and sheep with ruminal disorders. Sedimentation activity time and MBRT were also significantly altered in sheep having ruminal disorders as compared to control group. There was significantly difference between PCV, $\mathrm{Hb}$ and TEC of sheep suffering by ruminal disorders and control one. Further study on the bicarbonate level of sheep suffering from ruminal disorders and ration formulation of sheep feed will help to improve and control the problem.

\section{Competing interests}

The authors declare that they have no competing interests.

\section{Authors' contributions}

SM designed the study, collected data, performed the statistical analysis and drafted the manuscript. AA and BA participated in the study design and manuscript writing. All authors contributed to the data analysis, read and approved the final manuscript.

\section{Acknowledgments}

We wish to extend our sincere appreciation to University of Gondar for their financial and other supports. We also acknowledge the priceless support given by veterinary clinic workers and other Agricultural Offices experts of the study area for giving us valuable information's and other supports. 


\section{REFERENCES}

Agarwal N, Kamra DN, Chaudhary LC. Rumen microbial ecosystem of domesticated ruminants. InRumen microbiology: from evolution to revolution 2015 (pp. 17-30). Springer, New Delhi.

Tyagi, A., Arora, R., Shekhar, S., Rajora, V.S. and Arora, N., 2018. Therapeutic Assessment of Dried Rumen Liquor Preparations in Cases of Simple Indigestion in Buffaloes. Int. J. Curr. Microbiol. App. Sci, 7(7), pp.3769-3777.

Asrat M, Melkamu S. Current Advances in surgical management of Ruminal Disorders of bovine. Journal of Animal Research. 2015 Dec;5(4):683-93.

Kothari RK, Nathani NM, Mootapally C, Rank JK, Gosai HB, Dave BP, Joshi CG. Comprehensive Exploration of the Rumen Microbial Ecosystem With Advancements in Metagenomics. InMetagenomics 2018 Jan 1 (pp. 215-229). Academic Press.

Abdisa T. Study on the Prevalence of Bovine Frothy Bloat in and Around Kebele Lencha, Tokke Kutaye District, Oromia Region. Appro Poult Dairy \& Vet Sci. 2018;2(3):1-0.

Thrusfield M. Veterinary epidemiology. 3rd. Cambridgck e, USA: Blak Well Science Ltd. 2005:225-8.

McCurnin DM, Bassert JM. McCurnin’s Clinical Textbook for Veterinary Technicians.

Mohamed, A.E.A. (2014): Studies on Ruminal Disorders in Sheep. Journal of Assiut Veterinary Medicine, 8: 60:141.

Zein-Eldin MM, Ghanem MM, El-Raof AY, El-Attar HM, El-Khaiat HM. Clinical, haematobiochemical and ruminal changes during the onset and recovery of induced lactic acidosis in sheep. Biotechnology in Animal Husbandry. 2014;30(4):647-59.

Shah O, Shaheen M, Gupta G, Lather A, Nabi Su, Wani Ar, Hassan M. Clinical And HaematoBiochemical Changes In Alkaline Indigestion In South Down Breed Of Sheep In Kashmir Valley. Haryana Vet. 2013;52:63-5. 
Nurmeiliasari N, Priyanto R, Astuti DA, Takahashi J. Utilization of Rumen Mechanical Stimulator as Pseudo Fiber in Ruminant to Minimize Metabolic Problem.

Henning PH, Horn CH, Steyn DG, Meissner HH, Hagg FM. The potential of Megasphaera elsdenii isolates to control ruminal acidosis. Animal feed science and technology. 2010 Apr 21;157(1-2):13-9.

Lessire F, Knapp E, Theron L, Hornick JL, Dufrasne I, Rollin F. Evaluation of the ruminal function of Belgian dairy cows suspected of subacute ruminal acidosis. Vlaams Diergeneeskundig Tijdschrift. 2017;86(1):16-23.

Bailey G, Officer SV, Welfare O. Bloat in cattle and sheep.

Shah OS, Hussain T, Amin U, Rouf A, Dar ZA, Nabi SU, Shaheen M. Efficacy of different therapeutic regimens for simple indigestion in sheep.

Arya S. Effects of dietary inclusion levels of a low lignin hull, high-oil groat oat on the performance, carcass characteristics and rumen fermentation characteristics of feedlot cattle (Doctoral dissertation, University of Saskatchewan).

Penner GB, Beauchemin KA, Mutsvangwa T. Severity of ruminal acidosis in primiparous Holstein cows during the periparturient period. Journal of Dairy Science. 2007 Jan $1 ; 90(1): 365-75$.

Bharali DJ, Yalcin M, Davis PJ, Mousa SA. Tetraiodothyroacetic acid-conjugated PLGA nanoparticles: a nanomedicine approach to treat drug-resistant breast cancer. Nanomedicine. 2013 Dec;8(12):1943-54.

Blood DC, Radostits OM. Veterinary Medicine. 10"'ed. BailliereTindall, London. 2007.

Karapinar T, Dabak M, Kizil O, Balikci E. Severe thiamine deficiency in sheep with acute ruminal lactic acidosis. Journal of veterinary internal medicine. 2008 May;22(3):662-5.

Shah OS, Hussain T, Amin U, Rouf A, Dar ZA, Nabi SU, Shaheen M. Efficacy of different therapeutic regimens for simple indigestion in sheep. 
Reis LF, Minervino AH, Araújo CA, Sousa RS, Oliveira FL, Rodrigues FA, Meira-Júnior E, Barrêto-Júnior RA, Mori CS, Ortolani EL. Comparison of rumen fluid $\mathrm{pH}$ by continuous telemetry system and bench $\mathrm{pH}$ meter in sheep with different ranges of ruminal $\mathrm{pH}$. The Scientific World Journal. 2014;2014.

Suárez VH, Busetti MR. Health management practices and disease prevalence in dairy sheep systems in Argentina. Pesquisa Veterinária Brasileira. 2009 Nov;29(11):931-7.

Ding Z, Xu Y. A model for exploring lactic acidosis: 1. Model description. Belgian journal of zoology. 2006 Jul 1;136(2):117.

Randhawa SS, Dhaliwal PS, Gupta PP, Ahuja AK, Rathor SS. Studies of clinico-biochemical and pathological changes in the urea-induced acute rumen alkalosis in buffalo calves. Acta Veterinaria Brno. 1989;58(2-3):225-43.

Sales J. Effects of Saccharomyces cerevisiae supplementation on ruminal parameters, nutrient digestibility and growth in sheep: A meta-analysis. Small ruminant research. 2011 Sep 1;100(1):19-29.

Mousa E, Monzaly H, Shaat I, Ashmawy A. Factors affecting birth and weaning weights of native Farafra lambs in upper Egypt. Egyptian Journal of Sheep and Goats Sciences. 2013 Aug 1;8(2):1-0. 
Figures

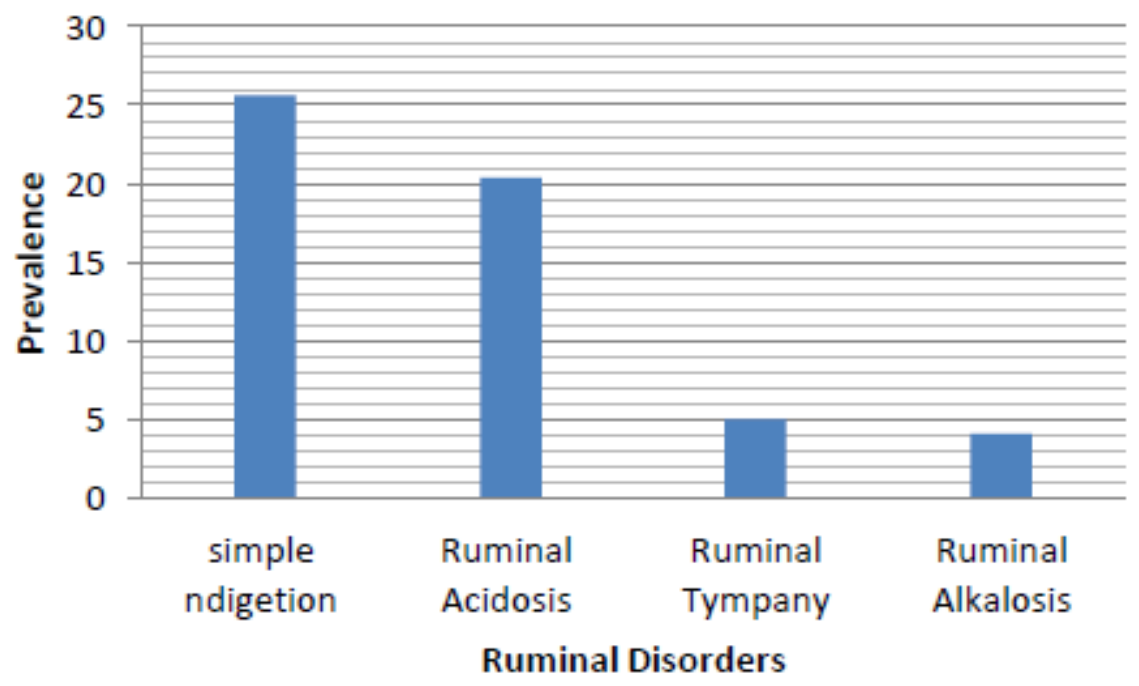

Figure 1

Prevalence of major ruminal disorders in sheep 